\title{
ENTRE A ESPERANÇA E O LIMITE: UM ESTUDO SOBRE A INCLUSÃO DE ALUNOS COM AUTISMO EM \\ CLASSES REGULARES
}

Dayse Carla Genero Serra

O estudo discute o processo de inclusão de alunos com autismo nas classes regulares de escolas públicas de duas prefeituras da baixada fluminense do Estado do Rio de Janeiro. Foi feita uma análise da legislação brasileira que fundamenta a inclusão educacional no Brasil, confrontando-a com a realidade das escolas, a partir de entrevistas realizadas com professores, familiares e colegas de sala.

\section{BANCA:}

Junia de Vilhena (Orientadora)

Aliny Lamoglia de Carvalho Sixel

Ana Cleide Guedes Moreira

Maria Helena Rodrigues Navas Zamora

Maria Inês G. F. Bittencourt

Data de defesa: 11/12/2008 